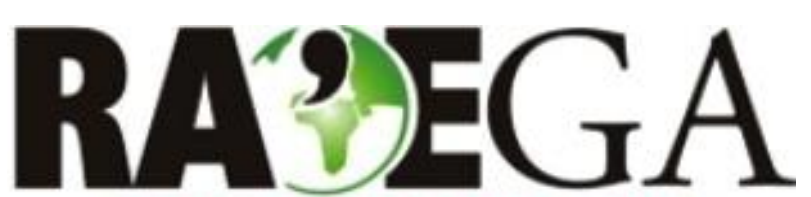

O ESPAÇO GEOGRÁFICO EM ANÁLISE

\title{
MAPPING OF PRIORITY AREAS FOR FOREST RECOVERY USING MULTICRITERIA ANALYSIS IN THE BRAZILIAN ATLANTIC FOREST
}

\author{
MAPEAMENTO DE ÁREAS PRIORITÁRIAS PARA RECUPERAÇÃO UTILIZANDO ANÁLISE \\ MULTICRITÉRIO NA FLORESTA ATLÂNTICA BRASILEIRA
}

Franciane Carla de Almeida ${ }^{1}$, Eduarda Martiniano de Oliveira Silveira², Lara Lopes de Paiva ${ }^{3}$, Fausto

Weimar Acerbi Junior ${ }^{4}$

\begin{abstract}
The collapse of a mining dam with 62 million cubic meters of mud in the Rio Doce basin resulted in the destruction of whole communities and large areas of the Atlantic Forest. As forest restoration activities are among the most costly conservation strategies, prioritization of restoration efforts is crucial. In the present article, this study mapped priority areas for forest recovery in a portion of the Rio Doce Basin (DO1) using a GIS-based (geographic information system) multicriteria decision analysis (MCDA) employing the weighted linear combination (WLC) method. Five factors with different weights were taken into consideration according to their level of importance: distance from the drainage network, distance from the native vegetation patches, slope, soil class and precipitation. A map of priority areas was produced in which $1.73 \%$ of the area was classified as very high priority for forest recovery, while $5.18 \%$ of the area was classified as high priority, $57.88 \%$ as medium priority, $1.34 \%$ as low priority and $0.00 \%$ as very low priority. The highest weights were attributed to the distance from the drainage network and the distance from native vegetation, revealing that areas of permanent preservation and those closer to forest fragments are priority areas for forest recovery. MCDA is a flexible and easy-to-implement method which generates maps with suitable solutions for forest recovery. The chosen approach can be replicated in regions that require support for decision making in environmental planning, such as the Pantanal biome, which is under considerable process of deforestation for the expansion of pastures.
\end{abstract}

Keywords: tropical forests; spatial analysis; analytical hierarchical process.

\section{RESUMO}

O rompimento de uma barragem de rejeitos de mineração com 62 milhões de metros cúbicos de lama, na bacia do Rio Doce, resultou na destruição de comunidades inteiras e grandes áreas de Mata Atlântica próximas às margens dos rios. Como as atividades de restauração florestal estão entre as estratégias de conservação mais dispendiosas, este trabalho teve como objetivo definir e mapear as áreas prioritárias para recuperação florestal em uma porção da Bacia do Rio Doce (DO1). Para isso, utilizou-se a análise de decisão multicritério (MCDA) associada ao SIG (sistema de informações geográficas) e baseada no método de combinação linear ponderada (WLC). Cinco fatores foram considerados, recebendo pesos distintos de acordo com sua importância: distância da rede de drenagem, distância do fragmento de vegetação nativa, declividade, classe de solo e precipitação. O resultado foi um mapa de áreas prioritárias onde $1,73 \%$ das áreas foram classificadas com muito alta prioridade para recuperação florestal, enquanto $5,18 \%$ das áreas foram classificadas com alta prioridade, $57,88 \%$ com prioridade média, 1,34\% com baixa prioridade e $0.00 \%$ com prioridade muito baixa. Os maiores pesos foram atribuídos aos fatores proximidade da rede de drenagem e proximidade de fragmentos de vegetação nativa, revelando que as áreas de preservação permanente e próximas a fragmentos florestais são áreas prioritárias para a recuperação florestal. A ADMC é um método flexível, de fácil implementação e produz mapas contendo soluções adequadas para conduzir ações de recuperação de forma rápida e eficiente. Este estudo pode ser replicado em diversas regiões que necessitam de apoio para a tomada de decisões no planejamento ambiental, como o bioma Pantanal, marcado pelo desmatamento para a expansão principalmente de pastagens.

Palavras chave: florestas tropicais; análise espacial; processo analítico hierárquico.

\footnotetext{
${ }^{1}$ Universidade Federal deLavras,Lavras/MG, email:almeidafeng@gmail.com

${ }^{2}$ Universidade Federal de Lavras, Lavras/MG, email: dudalavras@hotmail.com

${ }^{3}$ Universidade Federal de Lavras, Lavras/MG, email: lara.lpsp@gmail.com

${ }^{4}$ Universidade Federal de Lavras, Lavras/MG, email: fausto@dcf.ufla.br
} 


\section{MAPPING OF PRIORITY AREAS FOR FOREST RECOVERY USING MULTICRITERIA ANALYSIS IN THE BRAZILIAN ATLANTIC FOREST}

Recebido em: 26/05/2019

Aceito em: 22/07/2019

\section{INTRODUCTION}

The Brazilian Atlantic Forest is a globally important ecological hotspot (ARAUJO et al, 2015, p.659) and it is considered one of the most important ecoregions for biodiversity conservation in the world (MYERS et al, 2000, p.855). However, this ecosystem is also one of the most fragmented and most exploited Brazilian biomes, which for centuries has endured timber exploitation, agricultural development, farming, exotic tree plantations and hunting (SANTOS et al, 2018, p.414). Prior to European settlement, the Atlantic Forest had covered $c$. 130 million hectares, but at present only $12.4 \%$ of its original area remains (SOS MATA ATLÂNTICA, 2018).

Beyond the loss of biodiversity, humaninduced forest cover changes decrease water quality due to soil erosion, thus increasing nutrient and sediment loading in rivers (YANG et al, 2016, p.31). As restoration activities are among the most expensive conservation strategies worldwide (HOLL et al, 2003, p.491), the development of approaches for the prioritization of restoration efforts is crucial (FERNÁNDEZ; MORALES, 2016, p.1). Among these approaches, MultiCriteria Decision Analysis (MCDA) has been effectively used in forest restoration efforts, as it allows the aggregation of the criteria that represent critical characteristics at the landscape scale (VALENTE et al, 2017, p. 54). The integration of MCDA with a GIS (geographic information system) provides a powerful spatial decision support system which offers the opportunity to efficiently produce maps. Indeed, GIS is a powerful tool to analyze spatial data and to establish a process for decision support (HAMADOUCHE et al, 2014, p.419). Because of their spatial aggregation functions, MCDA methods can facilitate decision making in situations where several solutions are available, thus various criteria must be taken into account and decision makers are in conflict (MENG; MALCZEWSKI, 2015, p.32).
The collapse of a mining dam located in a Brazilian Atlantic Forest area on the $5^{\text {th }}$ of November 2015, which was considered one of the biggest environmental disasters in the country's history, resulted in the destruction of whole human communities by a river of mud and mining waste. This calamity affected Rio Gualaxo in the Brazilian district of Mariana, a tributary to Rio Carmo and ultimately Rio Doce. The flood affected 600 kilometers of riverbed and destroyed human and animal lives as well as several land cover classes (such as grasslands, urban areas and native vegetation) and permanent preservation areas (SILVEIRA et al, 2017 , p.554). More recently, on the $25^{\text {th }}$ of January 2019, another mining dam collapsed in the same region, in the city of Brumadinho, leaving 212 people dead and 93 missing (PEREIRA et al, 2019, p.122).

Mining dam collapses are examples of fast land conversion and degradation, but this region has also been affected by slower forms of conversion and degradation, such as deforestation and burning, which have resulted in large expanses of degraded areas. Thus, it is addressed the question of where is the best area to restore the native vegetation by mapping and identifying priority areas for forest recover in a portion of Atlantic Forest in Rio Doce Basin (DO1). A GIS-based multicriteria decision was used with the employment of the weighted linear combination (WLC) method for the aggregation of criteria.

\section{MATERIAL AND METHODS}

Rio Gualaxo, a tributary to Rio Doce which is located in the Brazilian district of Mariana in the central region of Minas Gerais (MG) state, was the main focus of this study due to the collapse of a mining dam that resulted in the destruction of permanent preservation areas and forest remnants. The study area covers a portion of the Rio Doce Basin (DO1), in MG state, where vegetation is predominantly composed of 


\section{MAPPING OF PRIORITY AREAS FOR FOREST RECOVERY USING MULTICRITERIA ANALYSIS IN THE BRAZILIAN ATLANTIC FOREST}

Atlantic Forest types (Figure 1a). DO1 represents $24.65 \%$ of the total area of the Rio Doce Basin, totaling $14,062 \mathrm{~km}^{2}$ (Figure 1b), and it is characterized by a hilly relief and abundant tablelands. The climatic conditions are typical of humid tropical highlands (SILVEIRA et al, 2017, p.556). The effects of the flood on the permanent preservation areas of Rio Gualaxu were clearly visible on the ground and from remotely sensed imagery (Figure 1c).
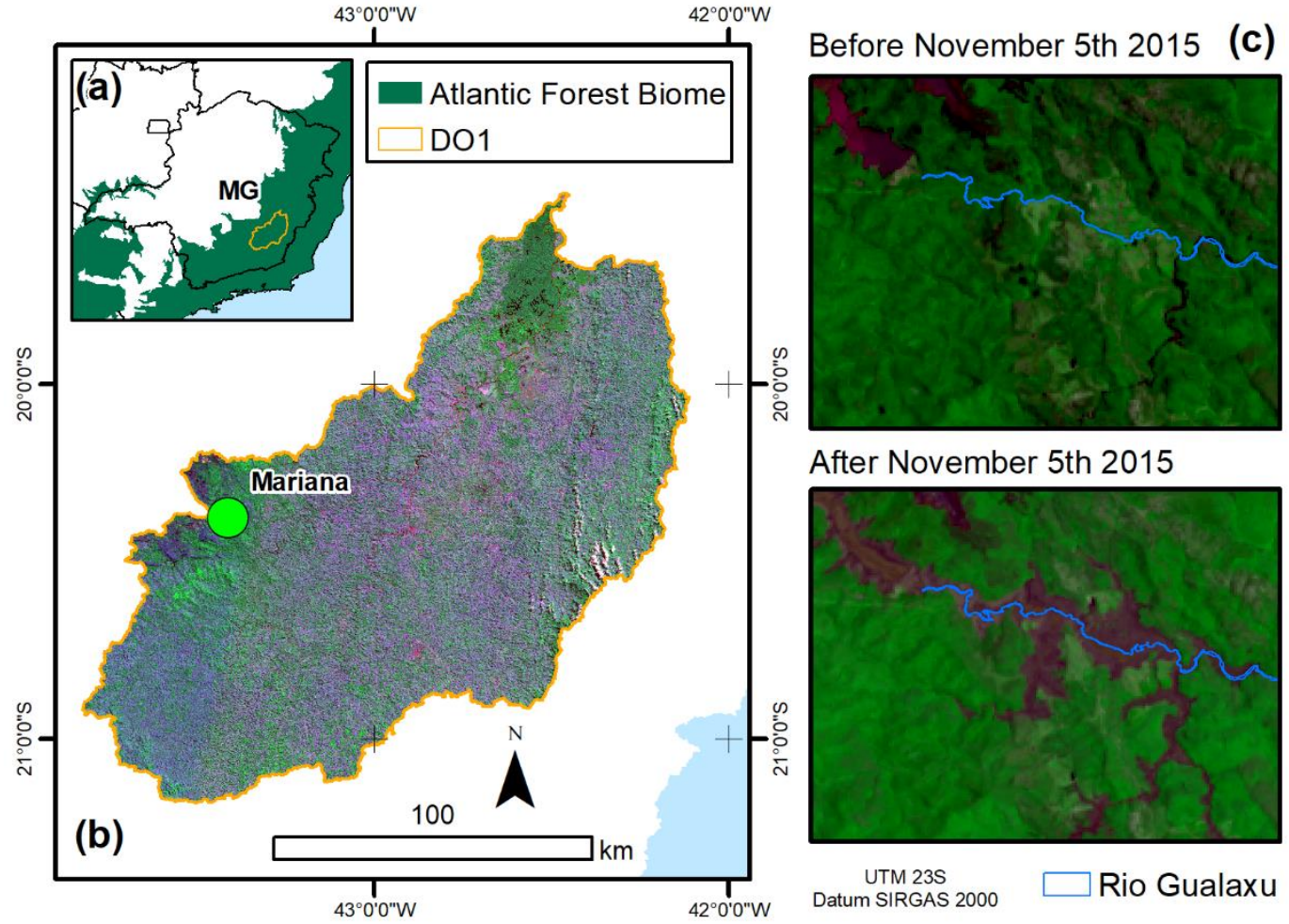

After November 5th 2015

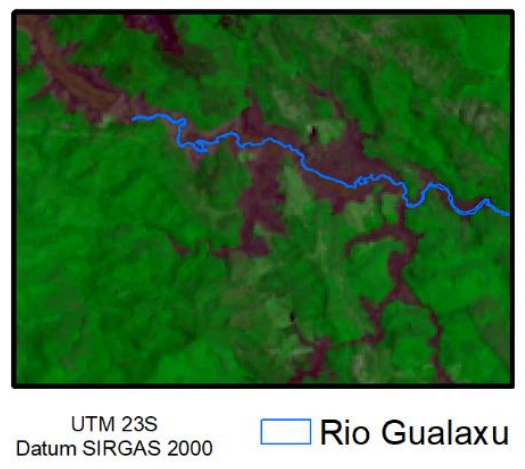

Figure 1. (a) Location of the study area (DO1) in MG state; (b) Landsat TM image R3 G2 B1 detailing the DO1 and; (c) Illustration of the effects of the flood in permanent preservation areas of Rio Gualaxu, before and after the environmental disaster. The main river is illustrated with a blue line. Source: Authors.

MCDA was used to define priority areas for forest restoration following four main steps (Figure 2). The following data sets were employed:

- Precipitation, acquired from WorldClim (HIJMANS et al, 2005, p.1966);

- Drainage network digitized by a skilled interpreter using images from Rapid Eye satellite (5 meters spatial resolution);

- Land cover map provided by Carvalho et al, (2006, p.37), manually edited by a skilled interpreter;

- $\quad$ Soil map (FEAM 2010);

- Digital elevation model (DEM) obtained from ALOS PALSAR. 


\section{MAPPING OF PRIORITY AREAS FOR FOREST RECOVERY USING MULTICRITERIA ANALYSIS IN THE BRAZILIAN ATLANTIC FOREST}

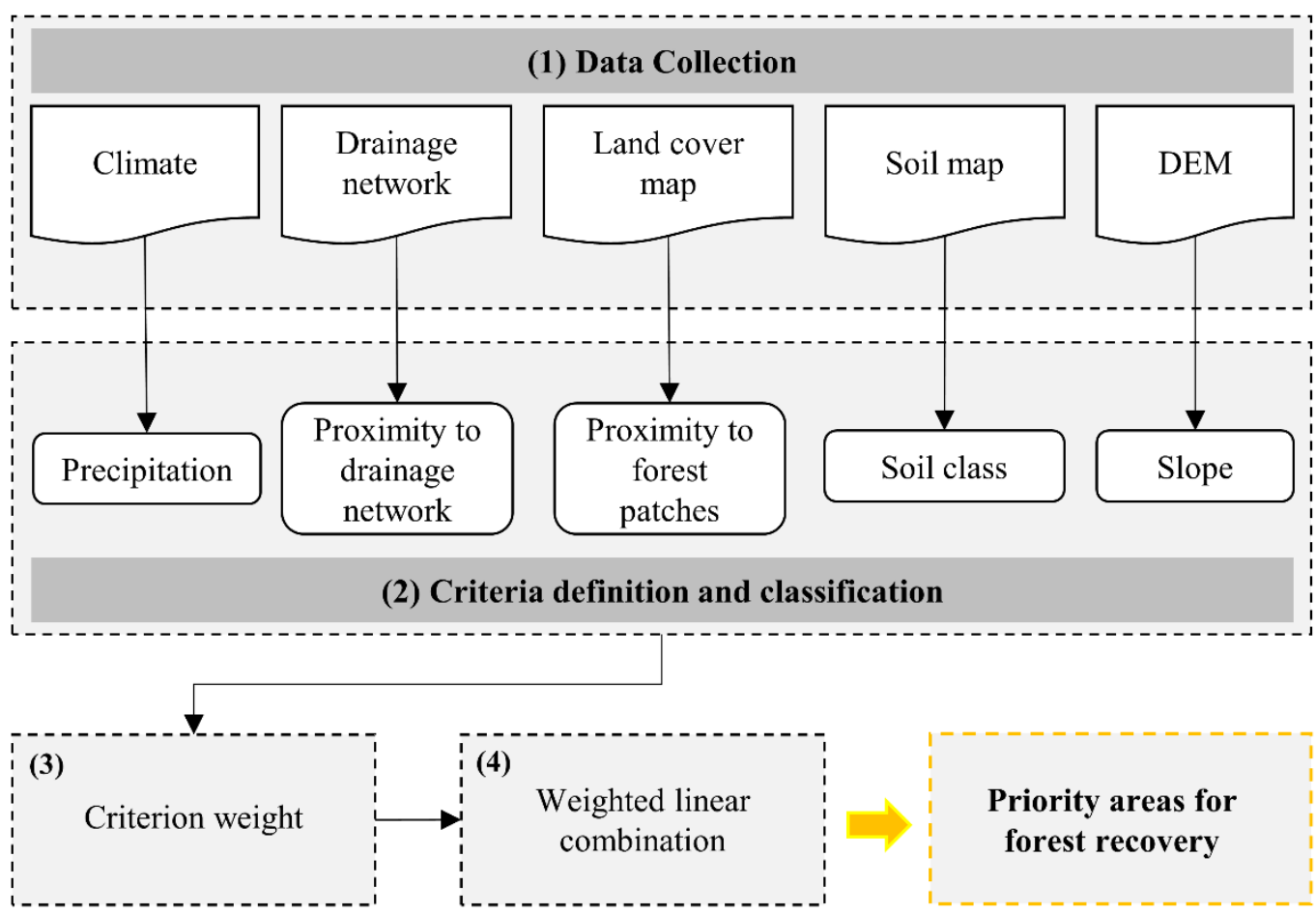

Figure 2. Methods flowchart detailing the four main steps to identify priority areas for forest recovery in a portion of the Rio Doce Basin. Source: Authors.

Criteria describing suitable landscape, terrain, edaphic and climatic characteristics and their relative importance for selecting priority areas for forest restoration were defined based on expert knowledge about the region and previous studies (FERNÁNDEZ; MORALES, 2016, p.03; HOLL et al, 2003, p.500; KIKER et al, 2005, p.95; MENG; MALCZEWSKI, 2015, p.30; RAMÍREZTORO et al, 2017, p.02; SARTORI, 2010, p.05; SILVA et al, 2017, p.02; VETTORAZZI, 2006, p.15; YANG et al, 2016, p.27).

Precipitation was chosen as a suitable climatic variable because its frequency, intensity and duration directly influence soil erosion. The proximity to drainage network was also selected as an important attribute because riparian forests contribute to soil and water conservation, reducing both erosion and silting of the rivers. Zones of 100, 200, 300 and 400 meters from the drainage network were created, with the closer ones having higher priority.

The proximity to forest patches obtained from land cover maps (e.g. CARVALHO et al, 2006, p.37) allows the strategic selection of areas that if restored, would form connections between forest fragments and ecological corridors that are important to the conservation of biodiversity (VALENTE et al, 2017, p.56). Using the land cover map of CARVALHO et al (2006, p.37), the Euclidean distance between the forest patches in the study area was calculated and assigned greater priority to areas closer to forest patches. Soil class and slope are directly associated with landslides, with some soil classes being more susceptible than others, depending on their texture, physical, and chemical characteristics. The slope of the land, which was calculated from a DEM, has a strong influence on the production of sediments, which affects both the quality and quantity of water. The greater the slope, the more susceptible the terrain is to erosion, thus higher priorities assigned to steeper slopes.

Land cover classes were considered where forest recovery would be inappropriate, such as water courses, areas already covered by native vegetation and urban areas, as restricted areas or constraints. This means that the final 


\section{MAPPING OF PRIORITY AREAS FOR FOREST RECOVERY USING MULTICRITERIA ANALYSIS IN THE BRAZILIAN ATLANTIC FOREST}

map of priority areas considered only the territory within the boundaries of the Rio Doce Basin (DO1), except for those areas with inappropriate land cover classes.

The analytic hierarchy process (AHP) was used to determine criteria weightings. By making pairwise comparisons at each level of the hierarchy, participants can develop relative weights (priorities) to differentiate the importance of the criteria. The scale recommended by Saaty $(1990$, p.15) is from 1 to 9 (Table 1). The assumption is that if attribute $A$ is absolutely more important than attribute $B$ and it is rated at 9 , then $B$ must be absolutely less important than $A$ and it is valued at $1 / 9$ (VALENTE et al, 2017, p.55).

Table 1. The Saaty intensity rating scale.

\begin{tabular}{ll}
\hline Intensity of importance & Remark \\
\hline 1 & Equal \\
3 & Somewhat more important \\
5 & Much more important \\
7 & Very much more important \\
9 & Absolutely more important \\
$2,4,6,8$ & Intermediate values
\end{tabular}

Source: Saaty (1990, p.15).

The consistency ratio (CR) was calculated to indicate any inconsistency that may have occurred during the pairwise comparison process. The procedure was executed in four steps: 1) the sum of the values of each factor in the columns was calculated and a new matrix was created; 2) in the lines, the geometric mean of each factor and the vector $\mathrm{V}$ were calculated; 3) a new matrix was created with normalized values in $\mathrm{V}$, which was achieved by dividing each value of vector $V$ by its summation; 4 ) the matrix obtained in stages 1 and 3 were multiplied and the highest eigenvalue was calculated ( $\lambda$ max).

CR (Equation 1 ) is designed in such a way that if $C R<0.10$, then the ratio indicates a reasonable level of consistency in the pairwise comparison matrix; if, however, $C R \geq 0.10$, then the ratio values are indicative of inconsistent judgments; in such cases the original values in the pairwise comparison matrix should be reconsidered and revised (VALENTE et al, 2017, p.54).

$C R=\frac{((\lambda \max -n)) /((n-1))}{R I}$ $\mathrm{n}=$ number of criteria;

$\lambda \max =$ highest eigenvalue;

$\mathrm{RI}=$ random index .

The Weighted Linear Combination (WLC) approach in the criteria aggregation was used to produce the priority map. In this method, the criteria are multiplied by their respective weights obtained from the AHP, then summed and multiplied by the constraints (Equation 2). In order to apply the WLC, the criteria generally need to be standardized since they may involve both qualitative (e.g. soil class) and quantitative (e.g. precipitation) attributes. The map was classified into five priority levels: very low, low, medium, high and very high. The analysis was performed in ESRI's package ArcGIS, version 10.4.1.

$$
s=\sum_{i=1}^{n} w_{i} \times x_{i} \times \prod_{j=1}^{k} C_{j}
$$

$w i=$ weight of factor $i$

$x i=$ normalized factor
Equation 1 
ALMEIDA, F. C., SILVEIRA, E. M. O., PAIVA, L. L., ACERBI JUNIOR, F. W.

\section{MAPPING OF PRIORITY AREAS FOR FOREST RECOVERY USING MULTICRITERIA ANALYSIS IN THE BRAZILIAN ATLANTIC FOREST}

$\mathrm{k}=$ number of restrictions

$\mathrm{Cj}=$ restrictions

\section{RESULTS AND DISCUSSION}

The criterion weights obtained are presented in Table 2 . The CR (consistency rate) was 0.06, indicating that the matrix had a reasonable level of consistency and was suitable for the production of a map of priority areas for forest restoration in Rio Doce Basin (DO1). The highest weight was obtained for proximity to drainage network criteria (0.51), indicating that the permanent preservation areas were identified as the most important areas for forest restoration (Figure $\mathbf{3 b}$ ).

Table 2. Pairwise matrix for the Rio Doce Basin (DO1). $C R=0.06 . A=$ Precipitation $(\mathrm{mm} / \mathrm{month}) ; B=$ Proximity to drainage network $(\mathrm{m}) ; \mathrm{C}=$ Proximity to forest patches $(\mathrm{m}) ; \mathrm{D}=$ Soil class; $\mathrm{E}=$ Slope.

\begin{tabular}{cccccc|cc}
\hline & A & B & C & D & E & Vector V & Weight \\
\hline A & 1 & $1 / 7$ & $1 / 5$ & $1 / 5$ & $1 / 5$ & 0.26 & 0.04 \\
B & 7 & 1 & 3 & 7 & 5 & 3.74 & 0.51 \\
C & 5 & $1 / 3$ & 1 & 3 & 3 & 1.72 & 0.24 \\
D & 5 & $1 / 7$ & $1 / 3$ & 1 & 1 & 0.75 & 0.10 \\
E & 5 & $1 / 5$ & $1 / 3$ & 1 & 1 & 0.80 & 0.11 \\
\hline Total & 23.00 & 1.82 & 4.87 & 12.20 & 10.20 & \\
\hline \multicolumn{7}{c}{ Source: Authors. }
\end{tabular}

These criteria were standardized, ranging from 1 to 3 (Table 3 ), following Crepani et al. (2001, p.32), where values closer to three mean a higher priority for forest recovery.

Proximity to forest patches (Figure 3c) was the second most important criterion for selecting priority areas for forest restoration. The spatial distribution of forest remnants is an indicator of landscape composition in terms of their degree of forest fragmentation. Experts highlight forest connectivity as the only way to obtain restoration at the landscape scale (ROY; TOMAR, 2000, p. 107).

Table 3. Criteria standardized. $A=$ Precipitation $(\mathrm{mm} / \mathrm{month}) ; B=$ Proximity to drainage network $(\mathrm{m}) ; C=$ Proximity to forest patches $(\mathrm{m}) ; \mathrm{D}=$ Soil class; $\mathrm{E}=$ Slope $(\stackrel{\mathrm{o}}{)}$.

\begin{tabular}{|c|c|c|c|c|c|}
\hline A & B & C & D & $\mathbf{E}$ & Classification \\
\hline$<50$ & $>400$ & $>400$ & Latosoils & $<2$ & 1 \\
\hline $50-75$ & - & - & - & - & 1.1 \\
\hline $75-100$ & - & - & - & - & 1.2 \\
\hline $100-125$ & - & - & - & - & 1.3 \\
\hline $125-150$ & - & - & - & - & 1.4 \\
\hline $150-175$ & 400 & 400 & & $2-6$ & 1.5 \\
\hline $175-200$ & - & - & - & - & 1.6 \\
\hline $200-225$ & - & - & - & - & 1.7 \\
\hline $225-250$ & - & - & - & - & 1.8 \\
\hline $250-275$ & - & - & - & - & 1.9 \\
\hline $275-300$ & 300 & 300 & Argsoil & $6-20$ & 2 \\
\hline $300-325$ & - & - & - & - & 2.1 \\
\hline $325-350$ & - & - & - & - & 2.2 \\
\hline $350-375$ & - & - & - & - & 2.3 \\
\hline $375-400$ & - & - & - & - & 2.4 \\
\hline
\end{tabular}


ALMEIDA, F. C., SILVEIRA, E. M. O., PAIVA, L. L., ACERBI JUNIOR, F. W.

\section{MAPPING OF PRIORITY AREAS FOR FOREST RECOVERY USING MULTICRITERIA ANALYSIS IN THE BRAZILIAN ATLANTIC FOREST}

$\begin{array}{cccccc}400-425 & 200 & 200 & \text { Cambisoil } & 20-50 & 2.5 \\ 425-450 & - & - & - & - & 2.6 \\ 450-475 & - & - & - & - & 2.7 \\ 475-500 & - & - & - & - & 2.8 \\ 500-525 & - & - & - & - & 2.9 \\ >525 & 100 & 100 & \text { Neosoil } & >50 & 3\end{array}$

Source: Crepani et al, (2001).

Slope (Figure 3e) was the third most important criterion for the selection of priority areas for forest restoration and it is directly linked to erosion because steep slopes transform potential energy into kinetics more quickly, thus increasing the velocity of the water bodies and their transport capacity. Therefore, these areas are more susceptible to erosion which may be a threat to conservation and forest preservation (ROSA et al, 2000, p.179).

Soil types (Figure $\mathbf{3 d}$ ) vary according to physical characteristics (structure, texture, permeability and density) and chemical properties. Some types such as latosols and argisols, which are more mature and deep soils, are less susceptible to erosion, while other types such as cambisols and neosols, which are younger, shallow and with low drainage, are more susceptible. These properties cause greater or less resistance to the action of water even under similar conditions of precipitation, topography, and land cover (BERTONI; LOMBARDI NETO, 1985, p.355).

Climate variables such as precipitation control weathering directly. For example, rain causes weathering of rocks and soil removal by water erosion. The direct impact of the droplets and the subsequent runoff are the active agents of water erosion. Thus, as precipitation increases, the classification value increases (Figure 3a). However, the five criteria act together in the soil erosion process, being essential in determining the priority areas for recovery. 


\section{MAPPING OF PRIORITY AREAS FOR FOREST RECOVERY USING MULTICRITERIA ANALYSIS IN THE BRAZILIAN ATLANTIC FOREST}

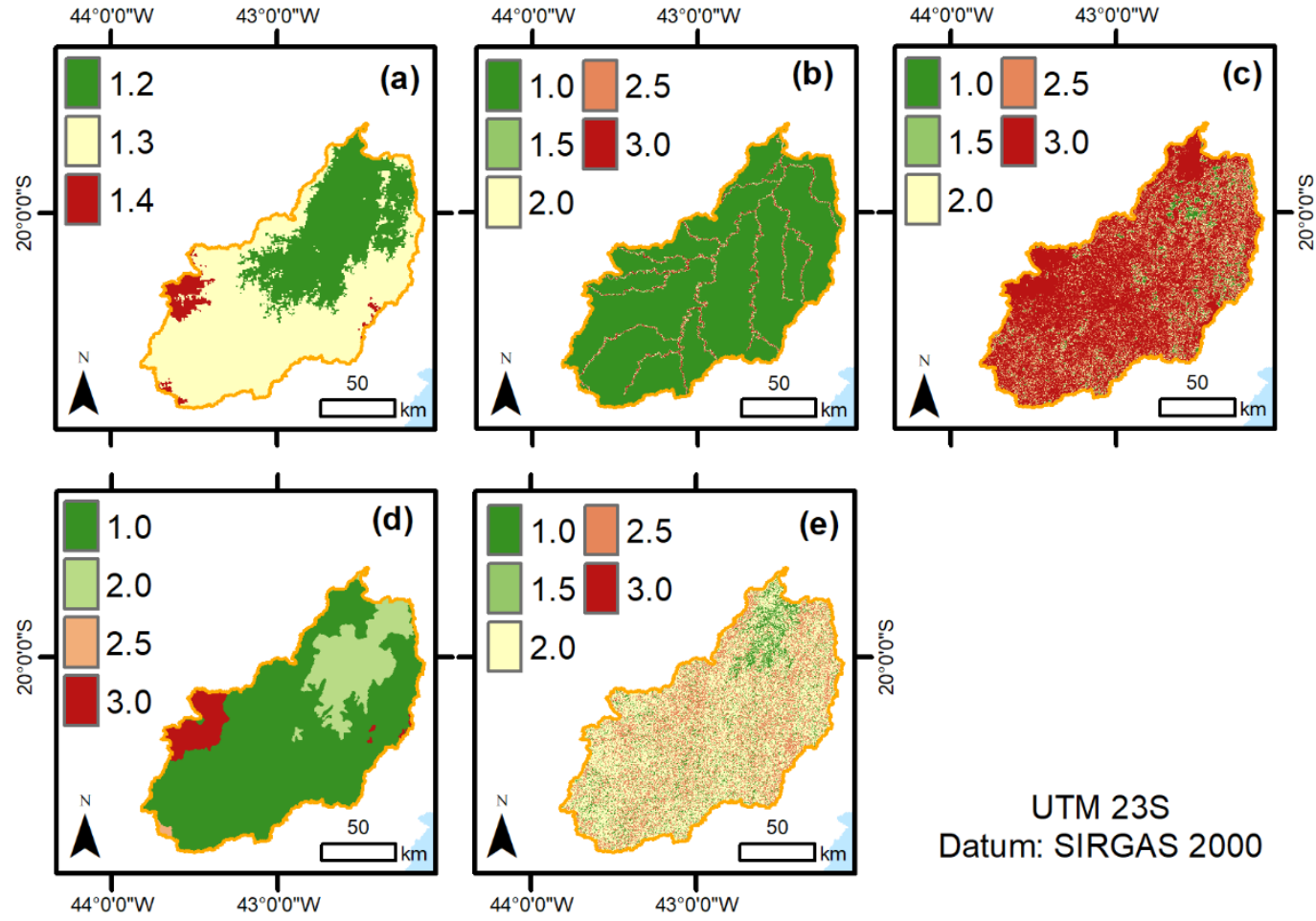

Figure 3. Criteria classification ranging from 1 to 3: (a) Precipitation (mm/month); (b) Proximity to drainage network (m); (c) Proximity to forest patches (m); (d) Soil class; (e) Slope (o). Source: Authors.

The resultant priority map (Figure 4), indicated $1.73 \%$ of the Rio Doce Basin (DO1) with very high priority (class 6) for forest recovery; $5.18 \%$ with high priority (class 5 ); $57.88 \%$ with medium priority (class 4 ); $1.34 \%$ with low (class 3 ) and $0.00 \%$ with very low priority (class 2 ); while restricted areas (class 1) represented $33.88 \%$ of the study area. From the total area of D01, 65\% presented from medium to very high recovery priority, indicating that the entire area is highly degraded. Considering the permanent preservation areas, $31.60 \%$ of the areas are in very high priority zones, $26.31 \%$ in high priority zones, $21.05 \%$ in medium and $15.80 \%$ in low priority zones. A total of $5.24 \%$ of the total area was in the restricted area (Figure 4b).

The large extent of areas classified as medium to very high priority for forest recovery is not only due to the environmental disaster caused by the collapse of the mining dam that occurred in the municipality of Mariana. The Rio Doce basin is a region with diversified economic activities such as coffee, sugarcane, and livestock. In addition, it has 10 hydroelectric plants in operation and the largest steel complex in Latin America, which is associated with mining and reforestation companies (STRAUCH, 1955, p.199). 


\section{MAPPING OF PRIORITY AREAS FOR FOREST RECOVERY USING MULTICRITERIA ANALYSIS IN THE BRAZILIAN ATLANTIC FOREST}

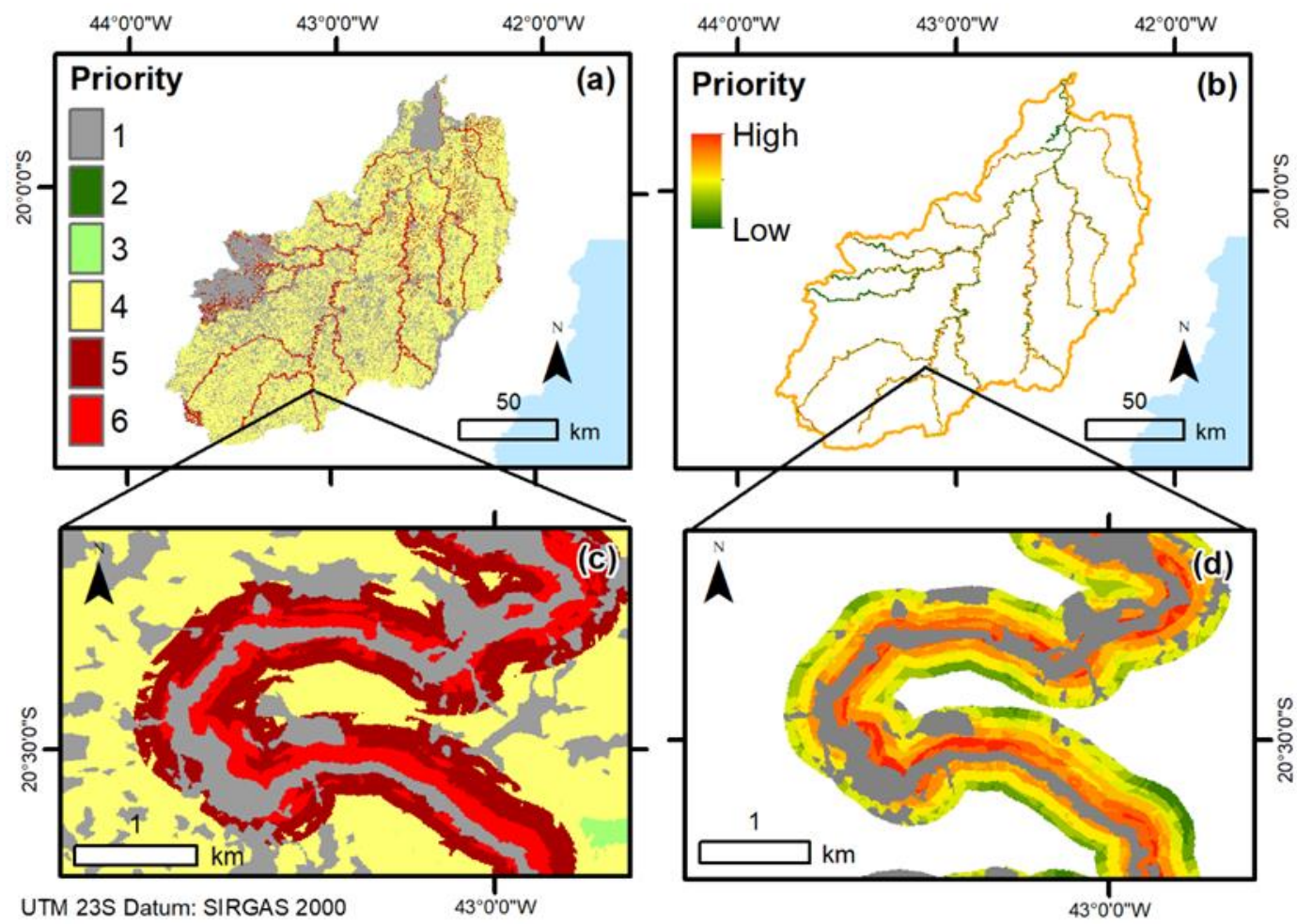

Figure 4. (a) Priority areas for forest restoration, (b) detailing the permanent preservation areas: (1) Restricted areas; (2) Very low; (3) Low; (4) Medium; (5) High and (6) Very high priority areas. Source: Authors. 


\section{MAPPING OF PRIORITY AREAS FOR FOREST RECOVERY USING MULTICRITERIA ANALYSIS IN THE BRAZILIAN ATLANTIC FOREST}

The method presented here may potentially be replicated in areas that play an important role in the global climate system such as the Pantanal biome (BACANI et al, 2016, p. 01). The Pantanal is one of the world's most biodiverse ecosystems, covering a continuous area of approximately $150,000 \mathrm{~km}^{2}$ (GONÇALVES et al, 2011, p. 242), and it is classified as a Biosphere Reserve and a World Heritage Site (SCHWERDTFEGER et al, 2016, p. 2590). However, the Pantanal biome is under considerable pressure from deforestation for pasture expansion, which places the ecological stability of this region in danger. Thus, accurate monitoring and understanding of land use/cover changes are of great importance to both the scientific community and local governments (HAN et al, 2015 , p. 426), which can be achieved in part by defining priority areas for restoration using MCDA and GIS analysis. In fact, these tools can be applied to many kinds of impacts, can be made site and temporally specific, and can be applied quantitatively as well as qualitatively (FINNVEDEN et al, 2003, p. 103).

\section{CONCLUSIONS}

Multicriteria analysis can be applied to diverse problems such as priority area mapping for forest recovery, connectivity between forest fragments, areas for landfill deployment, and urban planning. However, a truth-based database is necessary for the results to be satisfactory. According to our final map, the watercourses of the D01 sub-basin have permanent preservation areas with little or no vegetation cover, and the proximity of the drainage network was shown to be an important criterion for such analyses (highest weight). Much of the area in the DO1 sub-basin is degraded and has medium to very high priority for forest restoration.

\section{ACKNOWLEDGMENTS}

The authors would like to thank the "Fundação de Amparo à Pesquisa do Estado de Minas Gerais" (FAPEMIG - Brazil) and the "Conselho Nacional de Desenvolvimento Científico e Tecnológico" (CNPq - Brazil) for financing part of this study.

\section{REFERENCES}

ARAUJO, L.S.; KOMONEN, A.; LOPES-ANDRADE, C. Influences of landscape structure on diversity of beetles associated with bracket fungi in Brazilian Atlantic Forest. Biological Conservation, Oxford v .191, p.659-666, 2015.

BACANI, V. M; SAKAMOTO, A. Y.; QUÉNOL, H.; VANNIER, C.; CORGNE, S. Markov chains-cellular automata modeling and multicriteria analysis of land cover change in the Lower Nhecolândia sub region of the Brazilian Pantanal wetland. Journal of Applied Remote Sensing, Bellinghan, v. 10, n. 1, p. 1-20, 2016.

BERTONI, J.; LOMBARDI NETO, F.Conservação do solo. São Paulo: Ícone, 1985. 355 p.

CARVALHO, L.M.T.; SCOLFORO, J.R.; OLIVEIRA, A.D; MELLO, J.M.; OLIVEIRA, L.T.; ACERBI-JUNIOR, F.W.; CAVALCANTI, H.C.; FILHO, R.V.Procedimentos de mapeamento. Lavras: Mapeamento e Inventário da Flora e dos Reflorestamentos de Minas Gerais, 2006. p.3757.

CREPANI, E.; MEDEIROS, J. D.; HERNANDEZ FILHO, P.; FLORENZANO, T. G.; DUARTE, V.; BARBOSA, C. C. F. Sensoriamento remoto e geoprocessamento aplicados ao zoneamento ecológico-econômico e ao ordenamento territorial. São José dos Campos: Inpe, 2001. 124p.

Fundação Estadual do Meio Ambiente (FEAM) Mapa de solos do Estado de Minas Gerais. Disponível em: <http://www.dps.ufv.br/?page_id=742> . Acesso em: 28 junho 2018).

FERNÁNDEZ, I.C.; MORALES, N.S. A spatial multicriteria decision analysis for selecting priority sites for plant species restoration: a case study from the Chilean biodiversity hotspot. 


\section{MAPPING OF PRIORITY AREAS FOR FOREST RECOVERY USING MULTICRITERIA ANALYSIS IN THE BRAZILIAN ATLANTIC FOREST}

Restoration Ecology, Hoboken, v.24, p.1-10, 2016.

FINNVEDEN, G., NILSSON, M., JOHANSSON, J., PERSSON, A., MOBERG, A., CARLSSON, T. Strategic environmental assessment methodologies e applications within the energy sector. Environmental Impact Assessment Review, New York, v. 23, p. 91-123, 2003.

GONÇALVES, H.C.; MERCANTE, M. A.; SANTOS, E.T. Hydrological cycle. Brazilian Journal of Biology, São Carlos v. 71, N.1, p. 241-253, 2011.

HAMADOUCHE, M.A.; MEDERVAL, K.; KOURI, L.; REGAGBA, Z.; FEKIR, Y.; ANTEUR, D. GIS-based multicriteria analysis: an approach to select priority areas for preservation in the Ahaggar National. Arabian Journal of Geosciences, Heidelberg, v.7, n.2, p.419-434, 2014.

HAN, X.; CHEN, X.; FENG, L. Four decades of winter wetland changes in Poyang Lake based on Landsat observations between 1973 and 2013. Remote Sensing of Environment, New York, v. 156, p. 426-437, 2015.

HIJMANS, R.J.; CAMERON, S.E.; PARRA, J.L.; JONES, P.G.; JARVIS, A. Very high resolution interpolated climate surfaces for global land areas. International Journal of Climatology, Hoboken, v.25, p.1965-1978, 2005.

HOLL, K.D.; CRONE, E.E.; SCHULTZ, C.B. Landscape Restoration: Moving from Generalities to Methodologies. BioScience, Oxford, v.53, p.490502, 2003.

KIKER, G.A.; BRIDGES, T.S.; VARGHESE, A.; SEAGER, T.P.; LINKOV, I. Application of Multicriteria Decision Analysis in Environmental Decision Making. Integrated Environmental Assessment and Management, Hoboken, v.1, n.2, p. 95-108, 2005.

MENG, Y.; MALCZEWSKI, J. A.GIS-based multicriteria decision making approach for evaluating accessibility to public parks. Journal of Studies and Research in Human Geography, Bucuresti, v.9, n.1, p. 29-41, 2015.

MYERS, N.; MITTERMEIER, R.A.; MITTERMEIER, C.G.; FONSECA, G.A.B.; KENT, J. Biodiversity hotspots for conservation priorities. Nature, London, v.403, p.853-858, 2000.

PEREIRA, Luís Flávio; DE BARROS CRUZ, Gabriela; GUIMARÃES, Ricardo Morato Fiúza. Impactos do rompimento da barragem de rejeitos de Brumadinho, Brasil: uma análise baseada nas mudanças de cobertura da terra. Journal of Environmental Analysis and Progress, v. 4, n. 2, p. 122-129, 2019.

RAMÍREZ-TORO, W.; TORRES-MIRANDA, A.; RUIZSANCHEZ, E.; LUNA-VEGA, I.; OYAMA, K. A. Multicriteria Analysis for Prioritizing Areas for Conservation of Oaks (Fagaceae: Quercus) in Oaxaca, Southern Mexico. Tropical Conservation Science, Thousand Oaks, v.10, p.01-29, 2017.

ROSA, D.; MORENO, J. A.; MAYOL, F.; BONSÓN, T. Assessment of soil erosion vulnerability in westerm Europe and potential impact on crop productivity due to loss of soil depth using the Impelero model. Agriculture, Ecosystems and Environment, Amsterdam, v.81, p.179-190, 2000.

ROY, P. S.; TOMAR, S. Biodiversity characterization at landscape level using geospatial modeling technique. Biological Conservation, v. 95, p. 95-109, 2000.

SAATY, T.L. How to make a decision: The Analytic Hierarchy Process. European Journal of Operational Research, Amsterdam, v.48, p.9-26, 1990.

SANTOS, J.S.; LEITE, C.C.C.; VIANA, J.C.C.; SANTOS, A.R.; FERNANDES, M.M.; SOUZA ABREU, V.; NASCIMETNO, T.P.; SANTOS, L.S.; MOURA FERNANDES, M.R.; SILVA, G.F.; MENDONÇA, A.R. Delimitation of ecological corridors in the Brazilian Atlantic Forest. Ecological Indicators, Amsterdam, v.88, p.414-424, 2018.

SARTORI, A.A.C. Análise multicritérios na definição de áreas prioritárias à conectividade entre fragmentos florestais. 2010 Dissertação (Mestrado em Agronomia) - Faculdade de Ciências Agronômicas, UNESP, Botucatu, 2010.

SCHWERDTFEGER, J.; HARTMANN, A.; WEILER, M. $A$ tracer-based simulation approach to quantify seasonal dynamics of surface-groundwater 


\section{MAPPING OF PRIORITY AREAS FOR FOREST RECOVERY USING MULTICRITERIA ANALYSIS IN THE BRAZILIAN ATLANTIC FOREST}

interactions in the Pantanal wetland. Hydrological Processes, Hoboken, v. 30, n.15, p. 2590-2602, 2016.

SILVA, V.A.M.; MELLO, K.; VETTORAZZI, C.A.; COSTA, D.R.; VALENTE, R.A.Priority áreas for forest conservation, aiming at the maintenance of water resources, through the multicriteria evaluation. 1. Rev. Árvore, Viçosa , v. 41, n.1, Nov. 2017.

SILVEIRA, E.M.O.; ACERBI JÚNIOR, F.W.; MELLO, J.M.; BUENO, I.T. Object-based change detection using semivariogram indices derived from NDVI images: The environmental disaster in Mariana, Brazil. Ciência e Agrotecnologia, Viçosa, v.41, p.554-564, 2017.

SOS Mata Atlântica. Atlas dos remanescentes florestais da mata atlântica, período 2016-2017. Disponível em: <https://www.sosma.org.br/link/Atlas_Mata_Atl antica_20162017_relatorio_tecnico_2018_final.p df>.Acesso em: 02 mar 2019.

STRAUCH, N. A Bacia do Rio Doce. Rio de Janeiro: IBGE. 1955. p. 199.

VALENTE, A.R.; PETEAN, F.C. S.; VETTORAZZI, C.A. Multicriteria decision analysis for prioritizing areas for forest restoration. Cerne, Lavras, v.23, p.53-60, 2017.

VETTORAZZI, C.A. Avaliação multicritérios, em ambiente SIG, na definição de áreas prioritárias à restauração florestal visando à conserva de recursos hídricos. 2006. 151 p. Tese (Livre Docência): ESALQ/USP Escola Superior de Agricultura "Luiz de Queiroz" USP, Piracicaba. 2006.

YANG, W.; LIU, Y.; OU, C.; GABOR, S. Examining water quality effects of riparian wetland loss and restoration scenarios in a southern Ontario watershed. Journal of Environmental Management, London, v.174, p.26-34, 2016. 